\title{
Analysis of price fairness toward work quality and user satisfaction for architectural network
}

\author{
Amalia.N. Farini, Arief.S.B. Nugroho \\ Civil and Evironmental Engineering Department, Gadjah Mada University, Indonesia
}

\begin{abstract}
Construction business is still considered as a prominent business in the entire cities in Indonesia, including Yogyakarta. Contractors compete to get project either by tender or direct order. Both methods will certainly affect the price offered by the contractors. The research aims to understand how big the price gap between tender method and direct order for architectural works along with the work quality and the owner's satisfaction. Furthermore, several buildings in Yogyakarta become the sample of this research. The research data were collected using questionnaire, direct assessment, as well as direct interview with the contractors. The data obtained were analysed descriptively and statistically using SPSS software. The price gap between tender and direct order is $0,42 \%$ more expensive tender. On the tender method, the unit price increases followed by the increase in quality and user satisfaction. On direct order work, the price increase is followed by the increase in quality but decreased satisfaction.
\end{abstract}

\section{Introduction}

Construction services business in Indonesia is considered as a promising business in the present era. Indonesian National Income and Expenditure Budged (APBN) in year 2016 allocated about $6 \%$ of total spending on infrastructure development. Indonesian government's policy which focuses on procuring huge project on new infrastructure facilities has also affected construction business in Yogyakarta. It constitutes a promising opportunity for contractors to join the competition to get project's contracts. Often contractors offer an unreasonable low prices in order to win projects. However, unreasonable low price sometimes generate low quality of work and decrease satisfaction of building users.

The research aims to understand how the price gap of some architectural works obtained from tender method and direct order compare to the estimated price of Unit Cost Analysis of Indonesian National Standard. Second goal is to know the correlation between price along the work quality and the owner's satisfaction.

\section{Literature review}

\subsection{Price Fairness}

(Xia, Monroe, \& Cox, 2004) said that the reasonableness of prices is the acceptance of the price offered by definition by comparison and income. (Jacoby, 1976 in Xia, Monroe, \& Cox, 2004,) analyzes some relations to the concept of reasonableness between other people, social class, individual nature, and organization. (Sheikhzadeh, Antrianfar, Valiloo, \& Fahimi, 2012) determine seven theories govern price equality or price violations there are multiple ownership principles, distribution, procedures, interactional, equity theory, attribution theory, and prospect theory.

\subsection{Product quality}

Garvin (2007) describes the quality of the product as a collection of product characteristics which meets certain demand requirements. The product is considered qualified when its specifications meet the customer's expectations.
When this situation accure, customers will declare that the products are worthy and reasonable to be bought (Alex, \& Thomas, 2011). According to (Rao, Raghunathan, \& Solis, 1997), Product quality is used to understand and quantify consumers' need. (Nurcahyo, 2017) measures product quality using three variables, suitability, performance, and reliability. (Kurriawati, 2004) assess product quality based on five dimensions; Performance, Features, Reliability, Conformance, Aesthetic. (McDaniel, Lamb, and Hair, 2011) explains that consumers will see product quality from reliability, durability, easy maintenance, ease of use, trusted brand name and cheap price.

\subsection{Building users satisfaction}

(Zeithaml, Valarie, Parasuraman, Berry, \& Leonard, 1990) in a study entitled Delivering Quality Service: Balancing Customer Perceptions and Expectations, identify Factors that affect customer satisfaction are price, service quality, and product quality. Customer satisfaction on product or service can be evaluated in several ways, one of the most commonly used methods is referring to (Zeithaml, Bitner, \& Gremler, 2009) research entitled Services Marketing: Integrating Customer Focus Across the Firm, which assessment includes, tangibility, reliability, responsiveness, assurance, empathy.

(Kärnä, 2004) in his research entitled Analysing Customer Satisfaction and Quality in Construction, the Case of Public and Private Customers explained that customer satisfaction is a measuring tool for development of construction quality. Construction customer satisfaction is measured using 5 criteria, quality assurance and delivery, environmental and safety conditions in the work area, cooperative climate, organization members, and site and subcontractor supervision.

(Maloney, 2002) argues that one of the criteria for choosing a contractor is to see how satisfied customers are with the results and services provided by the contractor, factors to measure satisfaction is a relationship between customers and contractors, the ability of contractors to manage projects, contractor member skills, cost. 
(Yang \& Peng, 2008) in his research mentions that customer satisfaction is influenced by cost, quality, time, and communication. (Ahmed 1995) modelled customer satisfaction multiple linear regression methods with satisfaction criteria in the form of timeliness, client orientation, communication skill, cost, response to a complaint, and quality.

Referring to the references above, the criteria of customer satisfaction assessment in this study then can be determined, namely:

1. Cost, the fairness of price offered by a contractor

2. Quality, conformity to final results with plans and specifications

3. Service, communication, and alertness in responding to complaints

4. Timeliness, the speed of work and timeliness of completion of work

5. Skills, the ability of the contractor in managing the work

\subsection{Unit price of work}

Price (by Zeithaml, Valarie, Parasuraman, Berry, \& Leonard, 1990) in (Dessyastuty, 2003)) seen from the concept of cognitive is something that must be given to get the desired goods or services. The customer views the price as a picture of the value of a product so that there is a balance between the price and the value of a profitable product. Meanwhile, according to (Tjiptono, 2005) the price seen from the context of marketing services can be interpreted as the number of exchange rates that are used to obtain the desired service.

The unit price of work according to (Ibrahim, 2001) in a book entitled Plan and Estimate Real of Cost, the prices that used to plan construction work budget is material prices, worker fee, and the price of renting or purchasing equipment. Materials price is the price of materials around construction's area, the worker fee is the fee at a site, and the price of the tool is the purchase price or rental price, and the treatment price. It can be concluded that the unit price of work is influenced by 3 main factors which is materials, fee, and tools.

\subsection{Contractors selecting method}

The selection of contractors has several methods (LKPP, 2016) namely tender, direct appointments, direct order, and contests. Each method has their own advantages, disadvantages, and certain criteria for selecting the best method to be used. The method that will be discussed in this study is the tender method and the direct order method according to the purpose of the initial research.

(Hatush and Skitmore, 1997) show that the tender system with the lowest price has been used since 1848 in New York, the system was being implemented to save money and to create equal competition for all contractors. Tendering allows clients to choose contractors by considering the lowest prices. However, research suggests that choosing at the lowest price often creates problems in project completion. Lowering the price equals to lowering the quality, therefore there needs to be an evaluation of the procedures for selecting contractors (Puri, \& Tiwari 2014).

\subsection{Descriptive analysis}

Descriptive analysis according to (Sugiyono, 2008) is a descriptive statistic used to analyze and describe the results of research. The result of this statistic is only a general overview of research results such as maximum value, minimum value, mean, median, mode, and standard deviation.

The average analysis can be done using the following Equation 1:

$$
\bar{x}=\frac{\sum_{i=1}^{n} x_{i}}{n}
$$

Where $\bar{x}$ is average, $x_{i}$ is sample value the-I and $n$ is the number of sample.

\subsection{Normality test}

Parametric statistics require the data of each variable to be a normal distribution, therefore it is necessary to test the normality of the data to determine whether the sample data used normal distribution or not (Sugiyono, 2008). Normality testing can be done in several ways depending on the number of samples used. If there are plenty amount of samples then the normality test method chi-squared (X2) can be used, but if there are only a slight amount of data then the liliefors method or Kolmogorov-Smirnov (U2) can be used instead (Purwanto, 2011).

\subsection{Correlation test}

According to (Walpole, Ronald, \& Myers, 1995) the correlation test is used to measure the magnitude of the linear correlation between two or more variables. The relationship between two variables is said in the direction if the correlation is positive. The rule also applies to the opposite state of the relationship between the opposite variables if the correlation is negative.

1. Pearson product moment correlation test

Pearson product moment correlation analysis has a purpose to know how big relation and contribution of the independent variable with the dependent variable, below is the formula used to calculate product moment correlation coefficient Equation 4

$: r_{x y}=\frac{n\left(\sum x y\right)-\left(\sum x\right) \cdot\left(\sum y\right)}{\sqrt{\left\{n \cdot \sum x^{2}-\left(\sum x\right)^{2}\right\} \cdot\left\{n \cdot \sum y^{2}-\left(\sum y\right)^{2}\right\}}}$

Where $r$ is pearson product moment correlation, $x$ is independent variable, $y$ is dependent variable, $n$ is the number of sample.

(Riduwan \& Sunarto, 2014) has a limit to measure the relationship between the 2 variables listed in Table 1 .

Table 1. Correlation coefficient and its interpretation

\begin{tabular}{ll}
\hline Interval Coefficient & Correlation Rate \\
\hline $0,00-0,199$ & Very low \\
$0,20-0,399$ & Low \\
$0,40-0,599$ & Enough \\
$0,60-0,799$ & Strong \\
$0,80-1,000$ & Very strong \\
\hline
\end{tabular}

The value of $r$ has the condition $(-1 \leq r \leq+1)$, if the value of $r=-1$ then the variable has perfect negative correlation, if $\mathrm{r}=0$ then the variable has no 
correlation, and if $\mathrm{r}=1$ then the variable has a very strong correlation.

\subsection{Regression Analysis}

Regression analysis is used to determine the extent to which the dependent variable changes when the independent variable is changed or decreased, so this analysis has the benefit to decide whether the increase or decrease in the dependent variable can be done by increasing or decreasing the independent variable (Sugiyono, 2008). The regression model should be significant in order to be used to forecast the dependent variable of the independent variable (Purwanto, 2011).

\subsection{Statistical accuracy}

The regression function is said to be precise in predicting the actual value that can be measured based on its compatibility. This measurement method is done statistically using determination coefficient values and ttest statistic value.

\section{Coefficient determination test}

The coefficient of determination is a quadrant of the correlation coefficient which has a function to measure the ability of the model in explaining the variation of independent variables. $\mathrm{R} 2$ value has interval $0<x<1$. The value of $R 2$ close to 1 then the regression model is said to be better, otherwise, if the value of $\mathrm{R} 2$ is closer to the value 0 then the independent variable as a whole cannot explain the dependent variable. The correlation coefficient can be searched using Equation 5.

$R^{2}=\frac{\sum(\hat{y}-\bar{y})^{2}}{\sum(y-\bar{y})^{2}}$

Where $R 2$ is coefficient of determination, $y$ is observation value, $\hat{y}$ is value of y estimated with the regression model, $\bar{y}$ is average observation value.

2. The t-test is useful to know the significance of the influence of independent variables individually or individually to the dependent variable by providing the stipulation that other variables are constant. Ttest has a purpose to compare between t-count and $\mathrm{t}$ table or by looking at its significance value. The stipulations of significance in decision-making are described as follows:

a. Significance $>0.5$, Ho means acceptable

b. Significance $\leq 0.5$, meaning Ho is rejected

The value of $t$ count can be searched using Equation 6.

$t_{\text {count }}=\frac{b_{i}}{s_{b i}}$

Where $b i$ is coefficients of the i-th variable, $S b i$ is wrong raw bi (standard error bi regression coefficient)

The provisions of the value of t-test result are:

a. If t-count $\leq \mathrm{t}$-table, it can be interpreted as independent variable $(\mathrm{X})$ have an effect not significant to dependent variable (Y) individually either in togetheness or partially.

b. If t-count $>\mathrm{t}$-table, then it can be interpreted that the independent variable $(\mathrm{X})$ significantly affect the dependent variable (Y) individually either in togetherness or partially.

\section{Research methodology}

\subsection{Data}

The data used is divided into 2 , there are primary and secondary data.

1. Primary data which is the product quality and the costumer satisfaction obtained by direct assessment, interviews, and questionnaires.

2. Secondary data which the price obtained from several contractors who handle building projects in Yogyakarta.

\subsection{Method}

Stage of research methods are described as follows:

\subsubsection{Data collection}

Primary data and secondary data are collected in different ways.

1. Primary data collection is using a form of job assessment filled by five people who are experts in the field of building construction and user satisfaction questionnaire is collected by going to the occupants of buildings whose unit price is used as data in this research.

2. The collection of secondary data is divided into 2 ways.

a. The data obtained by contacting the contractors who have done the work of housing development either with the tender method or direct order in the region of Yogyakarta. The first data collected in the form of Budget Plan (RAB) in which there is the volume of work and unit price of work items. The second data is the material specification data used to make the building. The emerging specification may be a brand of a material or a mixed design used to create a mixture.

b. Data analysis based on Indonesian National Standard is obtained from ministerial regulation number 28 / PRT / M / 2016 concerning the analysis of the unit price of work in public works field, while for the material unit price and worker fee using governor regulation of special region of Yogyakarta year 2017 about standard price of goods and service area.

\subsubsection{Data separation}

Data obtained from contractors are separated between project data procured by tender method and direct order. 


\subsubsection{Primary data analysis}

1. The answer of each questionnaire respondent quality and satisfaction is processed using semantic differential scale and tested the normality of whether the data has been normal distributed or not, if the data is not normally distributed then it is necessary to add data.

2. Data that have passed the normality test are further summed and averaged to obtain average quality data and average user satisfaction.

c. The average value of quality and satisfaction of each sub architectural work is depicted in a graph xy to determine the level of decrease or increase of each variable.

d. The data used to create the next graph of correlation testing to find out how strong the relationship between the quality and satisfaction of each sub architectural work.

\subsubsection{Secondary data analysis}

1. Data Grouping

The data are grouped by job type and specification. Data grouping is processed using Microsoft Excel computer program.

2. Unit Price Uniformity

Data budget plan that has been collected in accordance with the year of its implementation first uniformed into the year of discussion which in this study is the end of 2017. Uniformity of costs made in order to avoid price differences that are not normal considering every year there are changes in price that sometimes significant value. Uniformity is calculated using the inflation rate.

3. The unit price of the work item is analyzed descriptively to know the mean, standard deviation, and the variant of the data.

4. Normality test conducted after a descriptive analysis to determine whether the unit price data is normally distributed or not if the data is not normally distributed need to add data.

\subsubsection{Merging primary and secondary data}

1. The result of primary and secondary data recap presented in graph form to know its optimum value. A graph with price as variable $\mathrm{x}$ and satisfaction and quality as variable $y$.

2. The graph on each sub architectural work that has been made, tested the correlation to find out how strong the relationship between unit price with quality and unit price with satisfaction.

3. From the results of the correlation test can be concluded anywhere the work price unit has a relationship with the quality of results and user satisfaction.

\section{Result}

The study was conducted on 9 types of architectural work with specific specifications that can be seen in Table 3 . The price of each type of work was collected for further processing so that the average price, the highest price, and the lowest price for each type of work would be known.

The standard price used as a comparison between the auction price and the direct appointment price is obtained from the analysis of the unit price of the work contained in Minister Regulation of PUPR no. 28 / PRT / M / 2016. The price of materials and workers fee is obtained from the Yogyakarta Provincial Governor Regulation No. 72 Year 2017 on the standard price of goods and services area which can be seen in Table 2 and Table 3 .

The material described in Table 3 is the material used to calculate the standard unit price of 9 types of work for this study. The worker's fee and the material price are included in the Indonesia National Standard analysis which can be seen in Table 5 .

The difference in tender price by direct order can be determined from the average calculation analysis of the price within each job. Table 5 explains that there is a considerable price difference between the average tender price, direct appointment, and the INS on some types of work. The highest price difference is in the gypsum ceiling installation work. The INS price is $63.24 \%$ higher than the tender price, INS price is $53.35 \%$ higher than the direct order price, and direct order price is $21.19 \%$ higher than the tender price. The lowest price difference is in the interior wall paintwork with the Paint 1 brand is $0.01 \%$ higher compared to the INS price of tender, the tender price is $2.51 \%$ higher compared to the INS price, and the direct order price is also higher by $2.44 \%$ compared to the tender price. There are 5 works from 9 types of work in which the INS price is higher than tender price and direct order price, so it can be said that INS price tends to be larger than tender price and direct order price.

Furthermore, the selection of contractors by way of tenders within the framework of plastering wall can be concluded that it is directly proportional to quality and price, it can be seen in Figure 1 that contains price and quality. The price of direct orders is directly proportional to the quality produced but inversely proportional to the satisfaction. In general, the quality of direct orders is higher than the quality of the tender, while for satisfaction the tender is higher than the direct order.

Table 2. Standard price of worker fee of D.I. Yogyakarta Province.

\begin{tabular}{clcr}
\hline No & Workers & Unit & \multicolumn{2}{c}{ Price } \\
\hline 1 & Bricklayer & OH & 70,000 \\
2 & Head & OH & 70,000 \\
& bricklayer & & \\
3 & Workers & OH & 60,000 \\
4 & Foreman & OH & 75,000 \\
5 & Carpenter & OH & 70,000 \\
6 & Head & OH & 80,000 \\
& carpenter & & \\
7 & Painter & OH & 70,000 \\
8 & Head painter & OH & 75,000 \\
\hline *Source: Governor Regulation of YogyakartaSpecial Province Number. \\
72 Year 2017 & &
\end{tabular}


Table 3. Standard price of material on D.I. Yogyakarta Province.

\begin{tabular}{clcr}
\hline No & \multicolumn{1}{c}{ Material } & Unit & \multicolumn{1}{c}{ Price } \\
\hline 1 & Portland cement & $\mathrm{Kg}$ & 1,000 \\
2 & Sand & $\mathrm{m}^{2}$ & 234,000 \\
3 & Concrete tile & $\mathrm{Unit}$ & 68,200 \\
4 & Nail 2"-5” & $\mathrm{Kg}$ & 15,000 \\
5 & Plamur & $\mathrm{Kg}$ & 5,000 \\
6 & Based coat & $\mathrm{Kg}$ & 19,000 \\
7 & Exterior coating brand & $\mathrm{Kg}$ & 82,000 \\
& paint1 & $\mathrm{Kg}$ & 54,000 \\
8 & Interior coating brand & & \\
& paint1 & $\mathrm{Kg}$ & 101,000 \\
9 & Exterior coating brand & & \\
& paint3 & $\mathrm{Kg}$ & 23,000 \\
10 & Interior coating brand & & \\
& paint2 & $\mathrm{Sheet}$ & 69,000 \\
11 & Gypsum board & $\mathrm{Kg}$ & 24,000 \\
12 & Screw nail & $\mathrm{m}{ }^{2}$ & 52,000 \\
13 & Colored ceramic floor & $\mathrm{Kg}$ & 11,000 \\
14 & Colored cement & $\mathrm{Unit}$ & $3,150,000$ \\
15 & Closet &
\end{tabular}

*Source: Governor Regulation of YogyakartaSpecial Province Number. 72 Year 2017

In the installation work of gypsum ceiling for the selection of contractors by way of tender, the quality and satisfaction is decreased when the price become higher, while at the price of direct order, the price become higher and has better quality but decreased consumer satisfaction. Both correlation can be seen in Fig 2. Overall we can say that consumer satisfaction of direct order not influenced by quality.

It can be concluded that within the job list of gypsum ceiling for the selection of contractors by way of tenders, the price is directly proportional to the quality and satisfaction, it is seen in Figure 3 that when the price rises then the quality and satisfaction would go up. Both quality and satisfaction on the tender method are not rising significantly by the price. Meanwhile, the direct order prices are directly proportional to the product quality but inversely proportional to its satisfaction. Satisfaction of direct order method is decreased significantly by the price. Overall, direct order quality is higher than the tender quality.

In 40x40 floor works for the selection of contractors by way of tenders, it can be concluded that the price is directly proportional to the quality and satisfaction but quality is not rising significantly by the price, it is seen in Fig 4 that when the price increased the quality and satisfaction increased too. The direct order price is directly proportional to customer satisfaction, upside down to its quality. Both tenders and direct orders have the same quality at a price of around Rp125.000,00. Overall the quality of the tenders is higher than the quality of direct orders, while for the direct order satisfaction is higher than the tender.

Meanwhile, in 10x40 plint floor work for the selection of contractors by way of tenders, it can be concluded that the price is inversely proportional to the quality but directly proportional to satisfaction, it is seen in Fig 5 that when the price rises then the satisfaction increased but the quality tends to decrease. Direct order prices are directly proportional to customer satisfaction and product quality. Both tender and direct order method have the same quality in Rp30.000,00-Rp35.000,00 price range. Overall direct order quality and satisfaction is higher than the tender.

In interior paintwork work using paint1 brand for selection of contractor by way of tender, it can be concluded that the price is directly proportional to quality but inversely to satisfaction, it is seen in Figure 6 when the price rises and the quality increased and satisfaction decrease. The direct order price is directly proportional to the quality of the product but the satisfaction of the service decreases. Both tender and direct order method have the same customers satisfaction within Rp22.000,00Rp23.000,00 price range. In general, the direct orders quality is higher than the tenders.

Table 4. Results of the Description Analysis of Price

\begin{tabular}{|c|c|c|c|c|c|c|c|c|}
\hline \multirow[t]{3}{*}{ No } & \multirow[t]{3}{*}{ Work } & \multirow[t]{3}{*}{ Specification } & \multicolumn{6}{|c|}{ Price $(\mathrm{Rp})$} \\
\hline & & & \multicolumn{3}{|c|}{ Tender } & \multicolumn{3}{|c|}{ Direct Order } \\
\hline & & & Average & Maximum & Minimum & Average & Maximum & Minimum \\
\hline 1 & $\begin{array}{l}\text { Wall } \\
\text { Plastering }\end{array}$ & $1: 6$ & 57,571 & 65,670 & 44,700 & 57,159 & 65,000 & 50,000 \\
\hline 2 & $\begin{array}{l}\text { Gypsum } \\
\text { Plafond }\end{array}$ & $\begin{array}{l}\text { Hollow } \\
\text { Framework }\end{array}$ & 101,094 & 110,000 & 90,483 & 128,282 & 155,000 & 80,553 \\
\hline 3 & Plafond List & Gypsum & 19,408 & 30,191 & 11,640 & 20,411 & 27,308 & 12,876 \\
\hline 4 & Floor & $40 \times 40$ & 151,009 & 230,410 & 112,008 & 160,943 & 189,811 & 133,488 \\
\hline 5 & Floor Plint & $10 \times 40$ & 30,748 & 51,006 & 14,410 & 27,640 & 45,000 & 15,650 \\
\hline & Interior Wall & Paint1 & 23,750 & 27,535 & 20,700 & 24,343 & 27,00 & 21,090 \\
\hline 0 & Painting & Paint2 & 17,889 & 19,738 & 15,000 & 15,470 & 17,377 & 12,364 \\
\hline & Eksterior Wall & Paint3 & 40,444 & 45,959 & 35,802 & 39,076 & 42,883 & 35,968 \\
\hline 7 & Painting & Paint1 & 29,098 & 32,733 & 24,854 & 30,284 & 32,000 & 28,130 \\
\hline 8 & $\begin{array}{l}\text { Monoblock } \\
\text { Instalation }\end{array}$ & $\begin{array}{l}\text { Brand TW } \\
421 \mathrm{~J}\end{array}$ & $3,253,591$ & $3,757,240$ & $2,754,768$ & $2,934,845$ & $3,200,000$ & $2,697,599$ \\
\hline 9 & Tile Roof & $\begin{array}{l}\text { Concrete } \\
\text { Tile }\end{array}$ & 81,669 & 97,081 & 72,000 & 80,643 & 110,723 & 69,046 \\
\hline
\end{tabular}



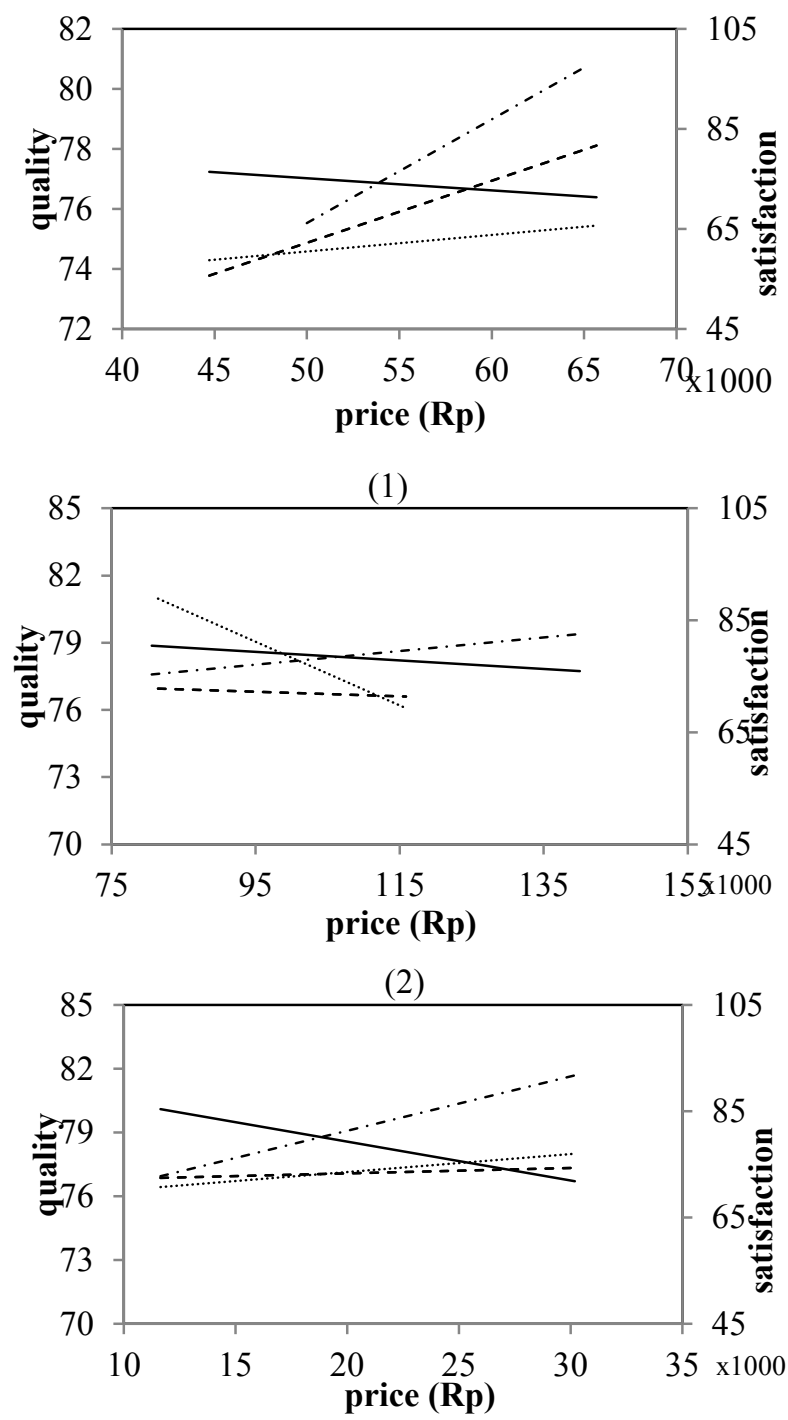

(3)

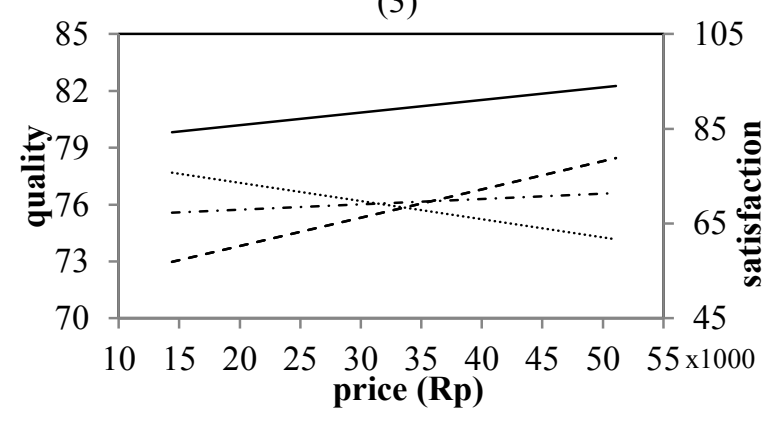

(4)

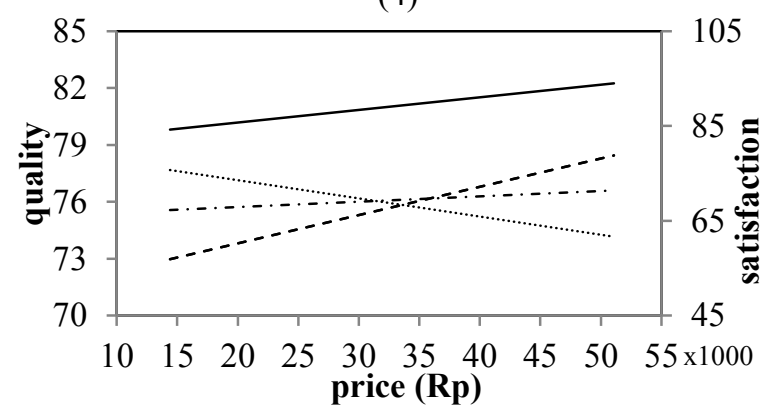

(5)
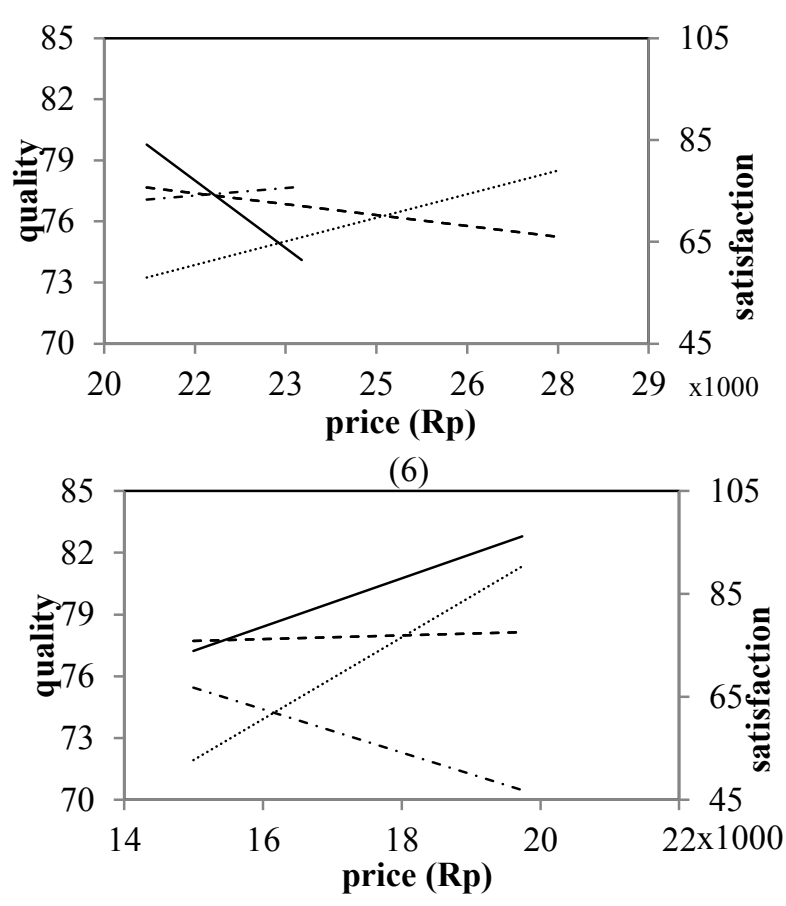

(7)

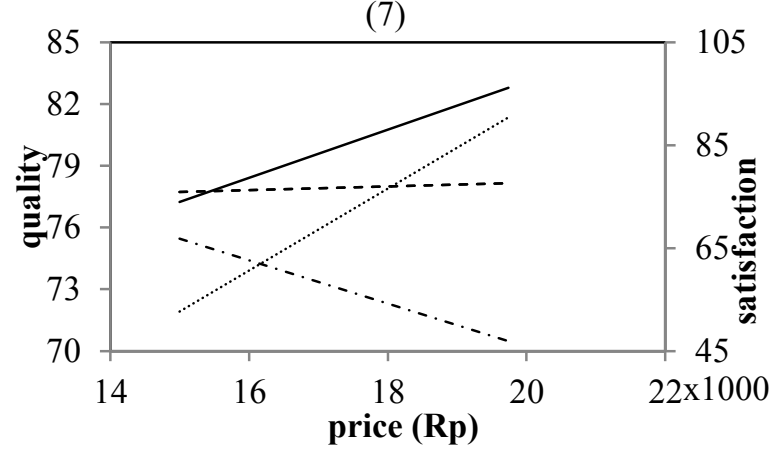

(8)

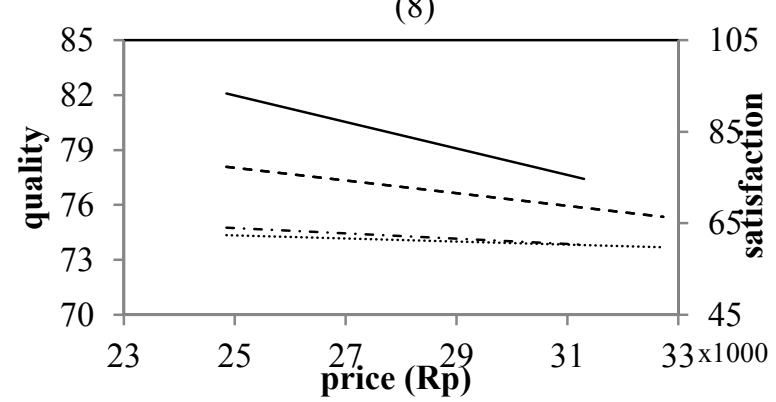

(9)

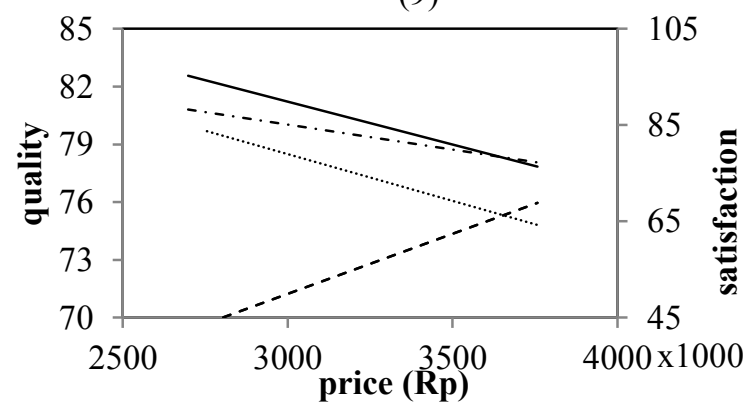

(10)

Fig 1. Correlation between price, quality, and satisfaction of architectural work (1) plastering wall, (2) gypsum ceiling, (3) ceiling list gypsum, (4) $40 \mathrm{~cm} \times 40 \mathrm{~cm}$ floor, (5) $10 \mathrm{~cm} \times 40 \mathrm{~cm}$ floor plint, (6) interior painting using paint1, (7) interior painting using paint2 brand, (8) exterior painting using paint3 brand, (9) exterior painting using paint1 brand, (10) monoblock installation.

* ------ Tender quality -.-.- Direct order quality ---- Tender satisfaction — Direct order satisfaction 
Table 5. Price Gap Between Tender, Direct Order, and Indonesia National Standard

\begin{tabular}{|c|c|c|c|c|c|c|c|c|}
\hline \multirow{2}{*}{$\begin{array}{l}\mathrm{N} \\
\mathrm{O}\end{array}$} & \multirow[t]{2}{*}{ Work } & \multirow[t]{2}{*}{ Specification } & \multicolumn{3}{|c|}{$\begin{array}{l}\text { Average Price } \\
\text { (Rp) }\end{array}$} & \multicolumn{3}{|c|}{$\begin{array}{c}\text { Average Price Differences } \\
(\%)\end{array}$} \\
\hline & & & Tender & Direct Order & INS & T-INS & DO-INS & T-DO \\
\hline 1 & Wall plastering & $1: 6$ & 57,571 & 57,159 & 78,924 & -27.05 & -27.58 & 0.72 \\
\hline 2 & Gypsum plafond & $\begin{array}{l}\text { Hollow } \\
\text { framework }\end{array}$ & 101,094 & 128,282 & 275,066 & -63.24 & -53.35 & -21.19 \\
\hline 3 & Plafond list & Gypsum & 19,408 & 20,411 & 21,855 & -11.20 & -6.61 & -4.91 \\
\hline 4 & Floor & Ceramic $40 \times 40$ & 151,009 & 160,943 & 107,727 & 40.18 & 49.40 & -6.17 \\
\hline 5 & Floor plint & Ceramic $10 \times 40$ & 30,748 & 27,640 & 21,159 & 45.32 & 30.63 & 11.25 \\
\hline \multirow{2}{*}{6} & Interior Wall & Paint1 & 23,750 & 24,343 & 23,748 & 0.01 & 2.51 & -2.44 \\
\hline & painting & Paint2 & 17,889 & 15,470 & 15,688 & 14.03 & -1.39 & 15.63 \\
\hline \multirow{2}{*}{7} & Exterior Wall & Paint3 & 40,444 & 39,076 & 35,968 & 12.45 & 8.64 & 3.50 \\
\hline & Painting & Paint1 & 29,098 & 30,284 & 31,028 & -6.22 & -2.40 & -3.92 \\
\hline 8 & $\begin{array}{l}\text { Closet } \\
\text { Installation }\end{array}$ & Brand TW 421J & $3,253,591$ & $2,934,845$ & $3,449,040$ & -5.67 & -14.91 & 10.86 \\
\hline 9 & Tile Roof & Concrete Tile & 81,669 & 80,643 & 89,230 & -8.47 & -9.62 & 1.27 \\
\hline \multicolumn{2}{|c|}{ Mean } & & 346,025 & 319,918 & 377,221 & -0.90 & -2.24 & 0.42 \\
\hline
\end{tabular}

For interior painting work using paint 2 brand for the selection of contractor by way of tender, it can be concluded that it is directly proportional to the quality and consumer satisfaction, it can be seen in Figure 7 when the price rises then the quality and satisfaction increases. The direct order price is directly proportional to customer satisfaction but the quality of service products decreases. Tender quality and direct order customer satisfaction increase significantly by the price increase. Customer satisfaction on the tendering method tends to be stable and increase slightly against the price increase. Both tender method and direct order method have the same quality in price around Rp16.000,00. In general, the tender quality is higher than the direct order.

In the exterior work of painting work using paint3 brand for the selection of contractors by way of tenders, it can be concluded that the price is inversely proportional to quality but it is directly proportional to the satisfaction, it is seen in Figure 8 that when the price increases then the quality goes down, however the satisfaction is increases. Quality on tendering method tends to be stable and decrease slightly against the price increase. Direct order price is directly proportional to product quality but not to the satisfaction as it is decrease. Customers satisfaction on direct order method is not affected by quality. Overall the quality of tender is better than direct order quality.

In the exterior work of painting work using paint1 brand contained in Fig 9 explains that both tenders and direct orders have the quality and satisfaction that decreases when the price rises. We can say that tender and direct order customer satisfaction is not affected by the price increase. Quality of tendering and direct order method decreases by the price increase but not as significant as the customer satisfaction. Overall quality and customer satisfaction on direct order method is higher than tender. Both tender method and direct order method have the same quality in Rp25,000.00 - Rp31.000,00 price range.

The monoblock installation work found in Fig 10 explains that both tenders and direct orders have quality decrease when the price is rising. Tendering consumer satisfaction tends to increase as prices increase, whilst it occurs otherwise on direct orders. We can say that customer satisfaction of tendering method is not affected by the quality decrease. Overall, consumer satisfaction of tender is higher than the direct order.

\section{Conclusion}

1. The price gap between tender and direct order is $0,42 \%$ more expensive tender. The price gap between tender and Indonesia National Standard is $0,90 \%$ more expensive INS. The price gap between direct order and INS is 2,24\% more expensive INS.

2. The work with the tender method tends to increase in product quality and consumer satisfaction as the price increases, it is proven by 6 out of 11 architectural work experience of quality improvement and satisfaction.

3. The work with direct order method tends to increase in product quality and decrease in consumer satisfaction along with price increase, it is proven by 7 of 11 architectural work experience of quality improvement and decreasing of satisfaction.

4. Contractors need to know the other factors than price and quality to increase consumer satisfaction of direct order.

\section{Reference}

1. B. Ibrahim, Rencana dan Estimate Real of Cost (2001)

2. C. Mc. Daniel. W.C. Lamb, J.F.L, Hair, Introduction to Marketing, South, Western, Cenage Learning, $11^{\text {th }}$ Edition, (2011).

3. D. Alex, S. Thomas, Impact of Product Quality, Service Quality, and Contextual Experience on Customer Perceived Value and Future Buying Intentions, European Journal of Business and Management ISSN 2222-1905 (Paper) ISSN 22222839 (online), Vol 3, No 3, P. 307-315, (2011).

4. D. Garvin, Managing Quality: The Strategic and Competitive Edge. New York: Free Press, (2007). 
5. D. Puri, S. Tiwari, Evaluating The Criteria for Contractors' Selection and Bid Evaluation. International Journal of Engineering Science Invention ISSN (Online): 2319-6734, ISSN (Print): 2319 - 6726, V 3 Issue 7 ॥ PP.44-48, (2014).

6. Dessyastuty, V. (2003). Pengaruh Persepsi Produk, Persepsi Kualitas Layanan, dan Persepsi Kewajaran Harga Terhadap Kepuasan dan Loyalitas Pelanggan pada Bengkel Honda Ahass di Kota Yogyakarta . Yogyakarta: Tesis Magister Manajemen Universitas Gadjah Mada.

7. E. Nurcahyo, Analisis Kualitas Produk dan Kuallitas Pelayanan terhadap Kepuasan Konsumen untuk Meningkatkan Loyalitas Pelanggan Bikintopisatuan.com Yogyakarta, (2017)

8. J. Yang, \& S. Peng, Development of a Costumer Satisfaction Evaluation Model for Construction Project Management. Journal Buliding an Environment 43(4), 458-468, (2008).

9. L. Xia, K.B. Monroe, J. L. Cox, (The price is unfair! A conceptual Framework of price fairness perceptions. Journal of Marketing, 1-15, 2004, 68 (October))

10. LKPP. Buku Informasi Menetapkan Metode Pemilihan Penyedia Barang/Jasa (2016)

11. M. Sheikhzadeh, H. Antrianfar, F. Valiloo, \& M. Fahimi. Price Fairness. Working Paper, Graduate School of Management \& Economics, Shrif University of Technology, (2012).

12. N. Kurriawati, Pengaruh Kualitas Produk Terhadap Kepuasan dan Dampaknya Terhadap Loyalitas Konsumen. JurnaL of Management Studies Universitas Trunojoyo, Vol 8, No 1, 48-55 (2004)

13. Purwanto, Statistika Untuk Penelitian, (2011)

14. S. Kärnä, Analysing Customer Satisfaction an Quality in Cosntruction the Case of Public and Privat Customers. Nordic Journal of Surveying and Real Estate Research - Special Series 2, 67-80 (2004)

15. S.S. Rao, T.S. Raghunathan, L.E. Solis, A Comparative Study of Quality Practices and Results in India, China, and Mexico. Journal of Quality Management 2(2), 235-250, (1997)

16. Sudjana, Metode Statistika Edisi ke-6, (2005).

17. Sugiyono, Statistika Untuk Penelitian, (2008)

18. V.A. Zeithaml, M.J Bitner, \& D.D. Gremler. Services Marketing: Intregating Customer Focus Across the Firm, 5th ed. New York: McGraw-Hill, (2009).

19. W. F. Maloney, Construction Product/Service an Customer Satisfaction. Journal of Construction Engineering and Management, 522-529, (2002)

20. Walpole, E.Ronald, , \& R.H. Myers, Ilmu Peluang dan Statistika untuk Insinyur dan Ilmuwan, edisi ke4. Bandung: Penerbit ITB, (1995).

21. Z. Hatush, \& M. Skitmore, Evaluating contractor prequalification data: selection criteria and project success factors. Construction Management and Economics, 15: 129-147, (1997).
22. Zeithaml, A.Valarie, A. Parasuraman, Berry, \& L. Leonard. Delivering Quality Service: Balancing Customer Perceptions and Expectations. The Free Press, (1990). 